\title{
Minireview
}

\section{Microbial Community Analysis of the Phytosphere Using Culture-Independent Methodologies}

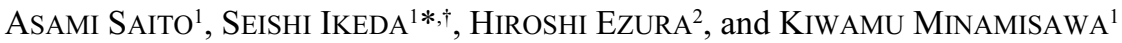 \\ ${ }^{1}$ Graduate School of Life Sciences, Tohoku University, 2-1-1 Katahira, Aoba-ku, Sendai, Miyagi 980-8577, \\ Japan \\ ${ }^{2}$ Gene Research Center, University of Tsukuba, 1-1-1 Tennoudai, Tsukuba, Ibaraki 305-8572, Japan
}

(Received March 9, 2007-Accepted March 27, 2007)

\begin{abstract}
The phytosphere is an attractive habitat for microorganisms due to an abundance of nutrients and relative environmental stability. The microorganisms that occupy this habitat assist in the uptake of nutrients from soils and can exert considerable influence upon the overall health of the plant. Recent technical advances in environmental microbiology have enabled the tracing and assessment of these microorganisms using rapid and simple molecular techniques without any culture-dependent bias. We herein review the current status of these modern molecular techniques in the study of plant-associated microbes, and summarize the issues relevant to the phytosphere from the aspect of both basic and applied science.
\end{abstract}

Key words: Community analysis, microbial diversity, plant-microbe interaction, phytosphere

\section{Introduction}

The phytosphere is a most attractive habitat for microorganisms due to the availability of many nutrients and its environmental stability. Conceptually, this unique environment consists of three main habitats for plant-associated microbes: the phyllosphere, the endosphere and the rhizosphere. Each of these three habitats provides a considerably diverse physical, chemical, and biological environment, and as a consequence can support a wide range of microbial groups. The microorganisms in these habitats assist plants in the uptake of several vital nutrients from the soil, such as phosphorous, potassium and nitrogen ${ }^{9,13,30,108,110)}$, and some of these organisms can exert considerable influence upon the overall health of the host plant ${ }^{26,27,39,80,101,104)}$.

\footnotetext{
* Corresponding author. E-mail address: sikeda@nbrc.nite.go.jp; Tel.: +81-438-20-5764; Fax: +81-438-52-2314.

† Present address: NITE Biological Resource Center (NBRC), National Institute of Technology and Evaluation (NITE), 2-5-8 Kazusakamatari, Kisarazu, Chiba 292-0818, Japan.
}

Conventional culture-dependent methodologies have provided useful information for evaluating microbial diversity in various environments including the phytosphere. However, these conventional methods are limited by strong inherent biases caused by the medium selected and the culture conditions. Moreover, a significant disadvantage of these techniques is the inability to culture most of the microbes in nature ${ }^{1)}$. In contrast, recent technical advances in environmental microbiology have enabled the evaluation of microbial diversity using rapid, simple, and less biased culture-independent molecular techniques ${ }^{54)}$. Culture-independent methodologies have now revealed that the majority of plant-associated microbes have not yet been cultured in the laboratory $2,51,117)$. These studies have thus provided vital clues regarding the abundance and spatial distribution of microbial groups in the phytosphere. However, the relationships between plants and phytosphere microbes are still largely unknown as the phytosphere contains a broad spectrum of microbes in terms of their degree of interaction with the host plant. These range from neutral microorganisms 
with no obvious effects upon the host plant to pathogens and mutualistic symbionts with deleterious and beneficial effects, respectively.

The use of currently available molecular techniques will clearly facilitate studies of plant-associated microbiology in both basic and applied research areas. However, these molecular techniques also have several limitations in terms of their application to microbial community analyses. In the present review, we first discuss technical issues in the application of culture-independent methodologies to the study of plant-associated microbes mainly focusing on bacteria and fungi. These issues include sampling, DNA extraction, PCR amplification, and DNA fingerprinting for a microbial community analysis of the phytosphere. Subsequently, we summarize the current status of the application of microbial community analyses in the fields of plant-associated microbiology.

\section{Plant managements for community analyses}

Microbial community analyses of the phytosphere are often performed in a controlled environment such as a greenhouse or a test field. In such cases, however, particular care needs to be taken with regards to plant management practices both before and during the analysis. Differences in management procedures, such as the application of fertilizers and pesticides, have been shown to cause structural changes to plant-associated microbial communities $^{32,70,97,106,116)}$. In addition, structural changes to microbial communities can be caused by differences in the levels of mycorrhizal fungi present in the rhizosphere ${ }^{69,71)}$. Hence, efforts must be made to maintain the homogeneity of the test soils as much as possible. Plant genotypic variation at the intraspecies level has also been reported to have a considerable impact on the composition of microbial communities ${ }^{57)}$, indicating the importance of considering the genetic purity of plant materials for community analyses of the phytosphere. Moreover, the growth stage of plants has been found to strongly influence microbial community structures $^{64,68,103)}$. These considerations may not apply in the case of a microbial community analysis using natural sampling sites for ecological studies, but could provide better insight for the interpretation of the results.

\section{Sampling of phytosphere materials}

The microbial habitats present in the phytosphere comprise diverse physical, chemical, and biological environments, and these differences require the use of a variety of sampling methods, depending on the target microbial community.

\section{(1) Phyllosphere}

The phyllosphere is defined as a microbial habitat mainly associated with the surface of the leaf. Prior to sampling of the phyllosphere, it must be considered that the composition of the microbial communities therein can be influenced by several factors including plant growth stage, leaf aging, pathogen infections, local temperature and humidity, and the accidental presence of transient saprophytes. Thus, the phyllosphere is a relatively variable and harsh environment compared to the endosphere and rhizosphere.

Two sampling methods should be considered when evaluating microbial communities in the phyllosphere. The first of these involves the extraction of microbial cells from the surfaces of leaves ${ }^{50,81,117)}$, either by simply washing tissue with a specific buffer ${ }^{50)}$, or in combination with sonication $^{117)}$. This method provides relatively pure environmental DNA in terms of both chemical and biological qualities for microbial community analyses. This is due to lower levels of contamination from plant debris during the extraction. This technique can also isolate high molecular weight DNA suitable for the construction of a large insert library such as a Bacterial Artificial Chromosome (BAC) library, when used in combination with chemical and enzymatic cell lysis procedures ${ }^{50)}$. It must be considered, however, that the efficiency with which cells are recovered from the surfaces of plant tissues may depend on factors such as plant/tissue type, the age of the tissue, and differences in the microbial groups present. An example of this has been shown in analyses of epiphytic microbes present on leaves and seeds, which are considerably affected by the large variability among samples ${ }^{81,117)}$. Dent et $a .^{15)}$ have previously employed a culture enrichment method involving seed imbibition for 16 hours, followed by tissue fractionation prior to DNA extraction. However, this procedure should be avoided when evaluating microbial diversity, because it can change the ratio of individual species in a population, particularly in the case of bacteria.

The second method involves the direct use of plant tissues for extracting DNA by bead-beating or the use of a mortar and pestle ${ }^{43,81)}$. In this case, samples contain both epiphytic communities (a microcosm in the phylloplane or spermoplane) and endophytic communities (the endophyllosphere or endospermosphere). This procedure is simple and faster than the first method. However, there is likely to be contamination by excess plant DNA which could affect subsequent molecular analyses by PCR. Although the appropri- 
ate choice of primers and reaction parameters could circumvent or minimize these potential biases, the amount of microbial biomass in the phyllosphere or in seeds is generally extremely small relative to the total plant material. Consequently, the analysis of communities in these tissues is often strongly biased by the presence of plant DNA and may in some cases be impossible to conduct ${ }^{81)}$. The sampling procedures for the phyllosphere have been successfully applied to the culture-independent analysis of the microbial diversity in seeds ${ }^{42,43,81)}$.

\section{(2) Endosphere}

The endosphere is defined as the microbial habitat inside of plant tissues. The sampling methods currently employed for analyzing the endosphere can also be divided into two main types. The first of these employs a procedure for sterilizing the surface of stem tissues using chemical reagents and/or flaming in order to eliminate contamination from epiphytic microbial $\mathrm{DNA}^{2,88)}$. This approach has been widely used for the isolation of endophytes (microbes inhabiting the endosphere $)^{78)}$, as well as for analyzing microbial communities in the endosphere ${ }^{2}$. The surface sterility of tissues is generally assessed by placing the sterilized tissues on appropriate growth medium. However, although this procedure is effective in eliminating potential contaminants during the isolation of endophytes based upon conventional culture methods, it may be insufficient to definitively establish the absence of microbial DNA derived from the dead cells of epiphytes (microbes inhabiting the phyllosphere on the surface of plant tissue).

Discrepancies between the results of community analyses of the endosphere using culturable and non-culturable methods may be partially due to the persistence of bacterial DNA on dead cells from the plant surface. Hence, some reports have proposed the aseptic peeling of the surfaces of the plant tissues prior to DNA extraction ${ }^{89,98)}$. However, as reported by Reiter and Sessitsch ${ }^{90)}$, aseptic peeling is impractical for some plant materials. In this case, the analysis of bacterial communities using cultivation-independent methods should be defined as a plant-associated community analysis that includes both epiphytes and endophytes.

The second method for analyzing communities of the endosphere utilizes a procedure for extracting bacterial cells from the insides of plant tissues ${ }^{29,90)}$. This comprises a mechanical disruption of the bacterial cells and has been shown to be effective in minimizing contamination by plant DNA prior to DNA isolation ${ }^{29,90)}$. Although this method is more laborious than the first, it facilitates a less biased analysis of endophytic microbial diversity.

\section{(3) Rhizosphere}

The rhizosphere was initially defined as the soil environment directly under the influence of the living roots of the host plant, but more recently the term has come to include both roots (endorhizosphere and rhizoplane) and root-associated soil (ectorhizosphere or rhizosphere soil) environments ${ }^{84)}$. Although the effects of the rhizosphere on the diversity of soil microbes can usually be observed by community analyses (Fig. 1), a precise physical definition of rhizosphere soils is extremely difficult as the degree of influence by the roots on neighboring soil environments can be affected by several factors including plant species, plant aging, and soil properties ${ }^{13,14,59,70,72,82,103,115,116)}$. For practical purposes, two sampling methods are usually employed when analyzing the communities of the rhizosphere. The first consists of the recovery of adherent soil by agitation

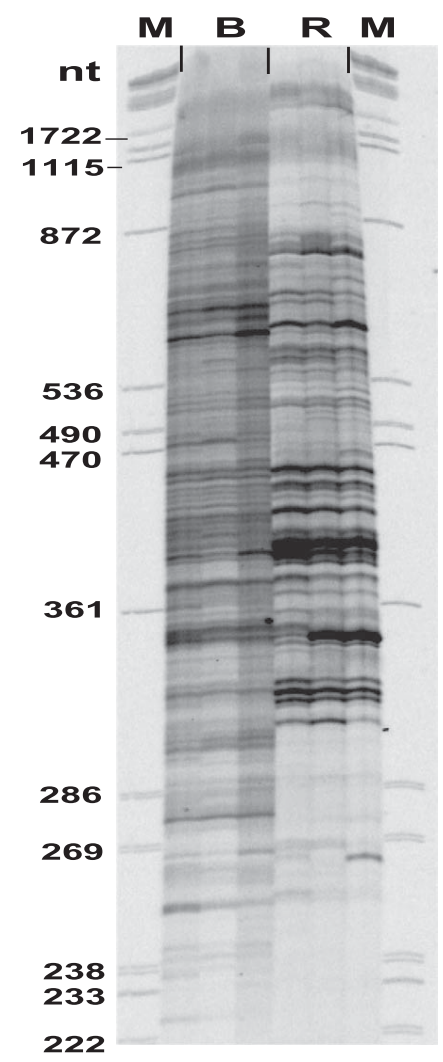

Fig. 1. RISA Profiles of the bacterial communities in maize rhizosphere. M, molecular size markers; lane B and R indicate bulk and rhizosphere soil samples, respectively. Triplicate results for each sample are shown. The leftmost numbers indicate marker fragment lengths. Fewer amplicons of increased intensity in the rhizosphere soil samples are considered to indicate rhizosphere effects. 
(shaking) of roots that have been decomposed carefully from the ground, either in air or water ${ }^{19,62,92)}$. In the case of a bacterial community analysis, the resulting rhizosphere soil fraction can then be subjected to cell extraction prior to DNA preparation.

The advantage of this method is that it can minimize contamination by plant tissues. However, the quality and quantity of the recovered rhizosphere soils can also be greatly affected by the handling procedures and by other factors such as the properties of both the soil and root systems. In addition, some researchers may use procedures for extracting bacterial cells from rhizosphere soils prior to DNA extraction that have various modifications such as bead shaking $^{37)}$ and sonication ${ }^{73)}$, making it difficult to directly compare the results. Another concern with this method is that excess amounts of bulk (non-rhizosphere) soil could be carried over into the rhizosphere fractions and thereby mask the impact of the rhizosphere upon the soil microbial community structures.

A second established method for sampling rhizosphere soil is the direct use of root systems with tightly adherent soil for DNA extraction, without the separation of plant tissues. This procedure recovers microbial DNA from the rhizoplane region and retains less bulk soil compared with the first method. As a result, the microbial DNA that is sampled could be expected to better reflect the microbial diversity in the rhizosphere. However, there are also some potential problems with this procedure. First, there may be contamination by excess plant DNA, in which case the appropriate choice of PCR primers and careful technique will be needed to minimize any potential bias. Second, several root tips are usually collected for DNA extraction, since it is practically impossible to extract microbial DNA directly from the entire root systems of most field crops. This may also bias the results due to the presence of a shift in the microbial community structures from the root to the basal area within the same root system ${ }^{116}$. Third, considerable spatial variability in the vertical distribution of soil microorganisms exists due to the presence of a surface gradient for several environmental factors, including oxygen availability and various nutrients. In order to control for these variations in a given sampling site, it is advisable that multiple samples be collected rather than the individual sample volume be increased.

\section{DNA extraction}

To date, several reports have described effective ways to extract nucleic acid from the phytosphere. However, the recovery of DNA/RNA from the phytosphere has yet to become routine, and still requires refinement of the extraction and purification conditions due to the extreme diversity of the physical, chemical, and biological properties of plant materials. It is also well recognized that the methods employed for extracting DNA or RNA can themselves bias the results of microbial community analyses in terms of both qualitative and quantitative interpretations of data ${ }^{66)}$. Moreover, whereas RNA-based examinations of microbial communities may provide a better indication of the naturally occurring profiles, the changes in expression levels of RNA may be too sensitive to environmental stress, such as that during the extraction process, to obtain reliable data and appropriate interpretation of the results.

In addition, RNA molecules are extremely labile both in vitro and in vivo, and therefore may not be an appropriate marker for evaluating certain environmental impacts. Consequently, soil DNA has been analyzed in the most recently reported studies of microbial communities in the phytosphere due to a lack of reliable methodologies for RNA extraction. We therefore mainly focus on the relevant considerations when extracting DNA from the phytosphere in this review. The details of some of the DNA extraction procedures that can be used for recalcitrant environmental samples, such as rhizosphere soils, are referred to our recent review ${ }^{47)}$.

The extraction of DNA usually involves three steps; cell lysis, extraction of nucleic acids, and subsequent purification steps. For the efficient lysis of microbial cells, beadbeating is often employed as the initial step of the extraction procedure. However, subsequent extraction/purification steps have tended to vary among different laboratories. Hence, until recently no established DNA extraction method had been reported for analyzing the communities of the phyllosphere and seeds. For analysis of the endosphere, bead-beating treatments of ground tissue have been conducted, followed by the standard phenol-chloroform extraction and/or CTAB extraction. Importantly however, these extraction/purification procedures were originally developed for extracting plant DNA, and were not actually intended for use with microbial DNA. Hence, these methods may not be adequate for the efficient extraction of DNA from microbial cells in the phytosphere.

We have shown in our recent study that a soil DNA extraction method could be adapted for the simple and rapid preparation of environmental microbial DNA directly from diverse biological materials, including plants and related agronomic products ${ }^{44)}$. More recently, a soil DNA extraction method has been employed in several studies for ana- 
Table 1. The influence of the extraction method on the quality of plant-associated DNA

\begin{tabular}{cccccc}
\hline \multirow{2}{*}{ Sample $^{\mathrm{a}}$} & \multicolumn{2}{c}{$\mathrm{OD}_{260} / \mathrm{OD}_{230} \mathrm{~b}$} & & \multicolumn{2}{c}{$\mathrm{OD}_{260} / \mathrm{OD}_{280}{ }^{\mathrm{c}}$} \\
\cline { 2 - 3 } \cline { 5 - 6 } & Soil kit $^{\mathrm{d}}$ & Plant kit & & Soil kit & Plant kit \\
\hline Leaf & $0.9 \pm 0.7^{\mathrm{f}}$ & $0.02 \pm 0.002$ & & $1.6 \pm 0.4$ & $2.0 \pm 0.05$ \\
Stem & $0.6 \pm 0.4$ & $0.02 \pm 0.005$ & & $1.6 \pm 0.02$ & $1.9 \pm 0.2$ \\
Root & $0.6 \pm 0.3$ & $0.02 \pm 0.0003$ & & $1.7 \pm 0.1$ & $1.8 \pm 0.2$ \\
\hline
\end{tabular}

a Tissues were subjected to bead-beating in a DNA extraction buffer prior to the extraction.

$\mathrm{b}$ The index for polysaccharide contamination.

${ }^{c}$ The index for protein contamination.

${ }^{\mathrm{d}}$ FastDNA SPIN Kit for soil. ${ }^{\mathrm{e}}$ FastDNA SPIN Kit. ${ }^{\mathrm{f}}$ Mean \pm S.D.

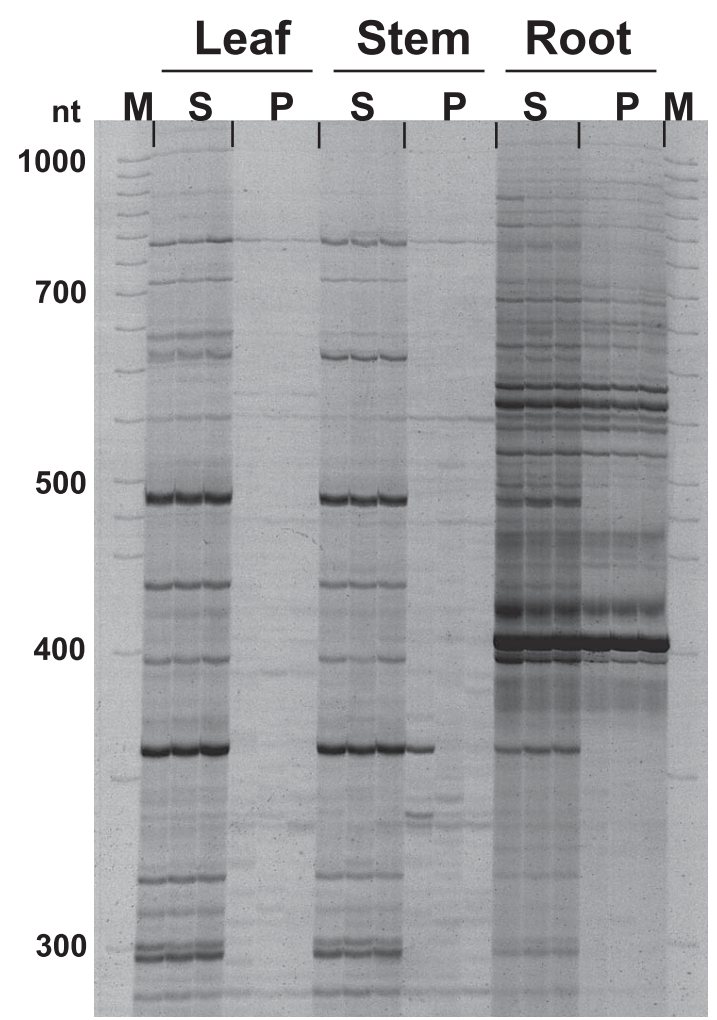

Fig. 2. RISA Profiles of the bacterial communities in the soybean phytosphere. Lane $\mathrm{M}$, molecular size markers; lane $\mathrm{S}$ and $\mathrm{P}$ indicate DNA samples prepared from each tissue using a soil DNA extraction kit and a plant DNA extraction kit, respectively. Triplicate results for leaf, stem and root tissues are shown. The leftmost numbers indicate marker fragment lengths. The influences of the DNA extraction methods on the results of the microbial community analysis are indicated by the differences in the number and intensity of the DNA bands between the $\mathrm{S}$ and $\mathrm{P}$ samples.

lyzing microbial communities in the phyllosphere and seeds ${ }^{28,32,42,43}$. Similarly, the most recent analyses of communities in the rhizosphere have successfully employed commercial soil DNA kits such as the FastDNA SPIN Kit for Soil (QBioGene/MP Biochemicals, Inc., Solon, OH, USA) and UltraClean Soil DNA Isolation Kit (Mo Bio Laboratories, Inc., Carlsbad, CA, USA). Because phytosphere samples often contain inhibitors of various enzymatic reactions including PCR, the success of these analyses is highly dependent upon the purity of the microbial DNA and thus upon the effectiveness of the method of extraction employed.

The impact of the two DNA extraction methods on analyses of the microbial communities of the phytosphere has been evaluated in our laboratory. The DNA prepared with a soil DNA extraction kit clearly showed a high ratio of $\mathrm{OD}_{260} / \mathrm{OD}_{230}$, which indicates less polysaccharide contamination, as compared to the DNA prepared with a plant DNA extraction kit (Table 1). On the other hand, the two methods gave similar values for the $\mathrm{OD}_{260} / \mathrm{OD}_{280}$ ratio as an index of protein contamination (Table 1). More importantly, these results reflected the differences of fingerprinting profiles as shown in Figure 2. These results clearly indicate the importance of the DNA extraction method employed, and of the quality of the environmental DNA when analyzing the microbial communities in the phytoshpere.

\section{PCR amplification}

PCR amplification of ribosomal RNA regions has been extensively used to study microbial diversity as this methodology takes advantage of the accumulation of such sequences in the public databases ${ }^{83)}$. In general, both small and large subunit rRNA genes and their intergenic spacer regions are utilized for primer design in microbial diversity studies as they are present in all organisms (Table 2). In most of the current reports of microbial communities, DNA fingerprinting techniques have been widely employed in combination with PCR amplification of ribosomal RNA regions ${ }^{47)}$. However, it has been estimated that microbial community analyses that employ culture-independent methodologies can detect only $1-2 \%$ of the total microbe populations in a complex environmental sample such as soil ${ }^{67}$. This is mainly due to the low resolution power of currently available fingerprinting techniques against the diversity of microbial communities in nature ${ }^{109)}$.

In cases where certain microbes are not easily detectable by the use of standard universal primer sets, taxon-specific primers have been shown to be sometimes effective (Table $2)^{2,36,56)}$. In the phytosphere, several microbial groups, such as Burkholderia, Pseudomonas, and Actinomycetes, are known to be important community members, and specific 
Table 2. PCR primers employed to analyze the microbial communities of the phytosphere

\begin{tabular}{|c|c|c|c|c|}
\hline Community or Organism & Target region & Method & Primer (Forward/Reverse) ${ }^{\mathrm{a}}$ & References \\
\hline \multicolumn{5}{|l|}{ Seed $^{b}$} \\
\hline Bacteria & 16S rRNA & DGGE & 341F-GC/534R and Anti-chloroF/534R, & 15) \\
\hline Bacteria & ITS $^{c}$ & RISA & ITSF/ITSReub & 43) \\
\hline Fungi & $18 \mathrm{~S}$ rRNA & DGGE & NS1/NS8 and Eukaryote specific primers & 15) \\
\hline Fungi & ITS & RISA & $1406 f / 3126 \mathrm{~T}$ & 43) \\
\hline \multicolumn{5}{|l|}{ Phyllosphere } \\
\hline Bacteria & 16S rRNA & DGGE & F341/R534 & 81) \\
\hline Bacteria & 16S rRNA & DGGE & $968-1401$ & 38) \\
\hline Bacteria & 16S rRNA & DGGE & primer1/primer2 & $50)$ \\
\hline Bacterioplankton & 16S rRNA & DGGE & PRBA338f/PRUN518r & 117) \\
\hline \multicolumn{5}{|l|}{ Endosphere } \\
\hline Bacteria & $16 \mathrm{~S}$ rRNA & DGGE & F341/R534 & 81) \\
\hline Bacteria & 16S rRNA & DGGE & F968-GC/R1378 & 2) \\
\hline Bacteria & 16S rRNA & DGGE & P388f/P518r & 97) \\
\hline Bacteria & 16S rRNA & T-RFLP & $243 \mathrm{f} / 1492 \mathrm{r}$ & 10) \\
\hline Bacteria & 16S rRNA & T-RFLP & $799 \mathrm{~F} / 1520 \mathrm{R}$ & 87) \\
\hline Bacteria & 16S rRNA & T-RFLP & $799 \mathrm{f} / \mathrm{pH}$ & 41) \\
\hline Bacteria & 16S rRNA & T-RFLP & $8 \mathrm{f} / 926 \mathrm{r}$ & 89) \\
\hline$\alpha$-proteobacteria & 16S rRNA & DGGE & $\mathrm{F} \alpha-\mathrm{U} / \mathrm{R} 1378$ and F968-GC/R1378 & 2) \\
\hline$\beta$-proteobacteria & 16S rRNA & DGGE & $\mathrm{F} \beta-2 / \mathrm{R} 1378$ and $\mathrm{F} 968-\mathrm{GC} / \mathrm{R} 1378$ & 2) \\
\hline Pseudomonas bacteria & 16S rRNA & DGGE & 8f-GC/PSMGx & 91) \\
\hline Actinomycetes & 16S rRNA & DGGE & F243-R518GC & 98) \\
\hline Actinomycetes & 16S rRNA & T-RFLP & $8 \mathrm{f} / 518 \mathrm{r}$ & 98) \\
\hline Fungi & 18S rRNA & DGGE & NS1/FR1-GC & 28) \\
\hline Fungi & 18S rRNA & DGGE & EF4f/NS3r & 97) \\
\hline \multicolumn{5}{|l|}{ Rhizosphere } \\
\hline Archaea & 16S rRNA & DGGE & $\mathrm{A} 46 \mathrm{f} / \mathrm{A} 1117 \mathrm{r}$ and $\mathrm{A} 340 \mathrm{f}-\mathrm{GC} / \mathrm{A} 533$ & 105) \\
\hline Bacteria & 16S rRNA & DGGE & F341-GC/R518 & 19) \\
\hline Bacteria & 16S rRNA & DGGE & F984-GC/R1378 & 37) \\
\hline Bacteria & 16S rRNA & DGGE & PRBA338f/PRUN518r & 116) \\
\hline Bacteria & 16S rRNA & T-RFLP & 27 Forward/1525 Reverse & $52)$ \\
\hline Bacteria & 16S rRNA & T-RFLP & $8-27 \mathrm{f} / 1507-1492 \mathrm{r}$ & 20) \\
\hline Bacteria & ITS & RISA & $1405 \mathrm{~F} / 23 \mathrm{R}$ & 3) \\
\hline Bacteria & ITS & RISA & ITSF/ITSReub & 45) \\
\hline Bacteria & 16S rRNA & SSCP & 133FN6F/248R5P & 102) \\
\hline Bacteria & 16S rRNA & SSCP & Com1/Com2-Ph & $96)$ \\
\hline$\alpha$-proteobacteria & 16S rRNA & DGGE & F203 $/$ /R1494 and F984GC/R1378 & 36) \\
\hline$\beta$-proteobacteria & 16S rRNA & DGGE & F948ß/R1494 and F984GC/R1378 & $36)$ \\
\hline Bacteroidetes & $16 \mathrm{~S}$ rRNA & DGGE & $\mathrm{C} 319 / 907 \mathrm{R}$ and $341 \mathrm{FGC} / 907 \mathrm{R}$ & 32) \\
\hline Burkholderia & 16S rRNA & DGGE & Burk3-GC/BurkR & 93) \\
\hline Actinobacteria & 16S rRNA & DGGE & F243/R1494 and F984GC/R1378 & $36)$ \\
\hline Actinomycete & 16S rRNA & DGGE & F243/R513-GC & 37) \\
\hline Methylotrophs & 16S rRNA & DGGE & $142 \mathrm{~F} / 533 \mathrm{R}$ & 23) \\
\hline Methylotrophs & 16S rRNA & DGGE & $197 \mathrm{~F} / 533 \mathrm{R}$ & 23) \\
\hline planctomycetes & 16S rRNA & T-RFLP & PLA-40F/1492R & 16) \\
\hline Pseudomonades & 16S rRNA & DGGE & $\mathrm{F} 311 \mathrm{Ps} / 1459 \mathrm{Ps}$ & 76) \\
\hline Streptomycete & 16S rRNA & DGGE & StrepB/Strep and E341f-GC/534r & 105) \\
\hline Eukaryote & 18S rRNA & DGGE & NS1-GC/NS2 & 76) \\
\hline Fungi & 18S rRNA & DGGE & $\mathrm{NS} 0 / \mathrm{EF} 3$ and $\mathrm{NS} 1 / \mathrm{FR} 1-\mathrm{GC}$ & 12) \\
\hline Fungi & 18S rRNA & DGGE & NS1/FR1-GC & 31) \\
\hline Fungi & 18S rRNA & DGGE & $\mathrm{NS} 1 / \mathrm{NS} 2+10-\mathrm{GC}$ & 107) \\
\hline Fungi & 18S rRNA & DGGE & NS1-GC/NS2 & 72) \\
\hline Fungi & ITS & RISA & $1406 \mathrm{f} / 3127 \mathrm{~T}$ & 45) \\
\hline Fungi & ITS & RISA & $2234 \mathrm{C} / 3126 \mathrm{~T}$ & 46) \\
\hline Fungi & ITS & T-RFLP & ITS 1F/ITS 4 & $56)$ \\
\hline VA fungi ${ }^{\mathrm{d}}$ & 18S rRNA & DGGE & AM1/NS31-GC & $60)$ \\
\hline Ascomycetes & ITS & T-RFLP & ITS 1F/ITS 4A & 56) \\
\hline Ascomycetes & ITS & DGGE & ITS5/ITS4A-GC & 113) \\
\hline Basidiomycetes & ITS & T-RFLP & ITS 1/ITS 4B & $56)$ \\
\hline
\end{tabular}

${ }^{\mathrm{a}}$ Two primer sets are shown for nested PCR. ${ }^{\mathrm{b}}$ Seed-associated microbial community.

${ }^{\mathrm{c}}$ Internal transcribed spacer region between the small subunit rRNA and large subunit rRNA genes. ${ }^{\mathrm{d}}$ Vesicular-arbuscular mycorrhizal fungi. 
primer sets for these microbes have been develop$\mathrm{ed}^{36,76,93,98,105)}$. By using group-specific primers, Costa et $a l .{ }^{13)}$ have also revealed that the extent of "rhizosphere effects" is largely dependent on the plant species, as well as the microbial groups under examination. Although a series of PCR primer sets are available as "universal primers", one should keep in mind that none of the presently available primers will amplify all sequences from the corresponding eukaryotic, bacterial, or archaeal domains.

In the case of microbial community analyses in the endosphere, it has been reported that the major portion of the clone library for a (partial) 16S rRNA gene fragment, which was amplified by using universal primers for eubacteria, often contains plant organelle-derived 16S rRNA sequences $^{98}$. In order to circumvent this problem, Chelius and Triplett ${ }^{8)}$ have reported the use of a primer (799f) that was designed for the specific amplification of bacterial $16 \mathrm{~S}$ rRNA gene sequences directly from root tissues. Although the successful application of this primer has been shown in several studies ${ }^{41,86)}$, it has further been reported that this primer set may have underestimated the diversity of microbial communities based on a comparison of the T-RFLP profiles with another set of primers ${ }^{41)}$. In addition, a bias of this primer for proteobacteria has been described by Reiter and Sessitsch ${ }^{90)}$. Recently, Rasche et al. ${ }^{87)}$ have shown that their 16S rRNA gene libraries, generated using the $799 \mathrm{f}$ primer, contain large numbers of clones assigned as chloroplast sequences, indicating that the specificity of this primer is also dependent upon the genotypes of the plant organelle. Caution should therefore be taken when microbial community analyses are conducted with this primer set.

While the assessment of bacterial diversity is less problematic due to the availability of universal primers for bacterial domains, fungal community analysis suffers from the effects of co-amplification of DNA from other eukaryotic organisms such as plants, algae, and nematodes ${ }^{61)}$. Although there are several studies that have reported attempts to resolve this problem ${ }^{56,58)}$, the specificity of these primer sets is still not sufficient, especially when applied to fungal community analyses of the phytosphere.

Due to the technical limitations in the purification of environmental DNA samples, it is not feasible to expect the complete elimination of all potential contaminants from the phytosphere materials. In order to overcome the potential inhibition of PCR by such contaminants, and to perform stable PCR amplifications, a series of special additives are often incorporated into the amplification mixtures. Among these, we recommend bovine serum albumin (BSA), as it is relatively inexpensive and has helped to generate stable
PCR amplifications in our laboratory for the analysis of diverse biological materials including phytosphere ${ }^{44,47)}$. Other additives such as GC-Melt (Clontech, Palo Alto, CA, USA) may also be of great assistance in PCR amplifications of target sequences containing a high GC content, as is the case for Actinomycetes.

While the microbial community in a phytosphere sample may contain a high level of diversity, it may also consist of taxonomically similar groups of microbes. In the latter case, mis-priming during PCR may become a major problem and result in the formation of chimeras during amplification. In order to minimize this, two strategies are usually employed for analyzing microbial communities. These are the use of a "hot start program"74) and a "touch down program"19), and these conditions can also be used in combination.

\section{Fingerprinting techniques}

There are four principal fingerprinting techniques that have been widely applied to microbial community analyses of the phytosphere. These are denaturing gradient gel electrophoresis (DGGE), single strand conformation polymorphism (SSCP), terminal restriction fragment length polymorphism (T-RFLP), and ribosomal intergenic spacer analysis (RISA). The principles, advantages, and disadvantages of these techniques have been described in recent reviews ${ }^{47,55)}$. Therefore, we have herein focused on the current status of the application of these techniques to microbial community analyses of the phytosphere in the present review.

\section{RNA-based community analysis}

DNA-based community analyses do not necessarily reflect the metabolic activity or prove the viability of the corresponding organisms, due to the presence of dead cells or extracellular DNA in the environment under study. Hence, a RNA-based community analysis is more suitable for elucidating the metabolically active members of a bacterial population, since the amount of rRNA can generally be correlated with the growth activity of bacteria ${ }^{144}$. To date, several reports have described the results of RNAbased community analyses, and distinct differences have been observed between DNA- and RNA-based analyses $^{18,57,90,91,100)}$. In these studies, the RNA-derived community profiles were found to be less complex than their DNAderived counterparts. As a consequence, one of the most recent achievements in phytosphere microbiology is the application of stable isotope probing (SIP) in combination 
with RNA-based fingerprinting ${ }^{85)}$. Plant roots release 1$25 \%$ of their net photosynthetic metabolites as soluble and insoluble compounds into the rhizosphere ${ }^{75)}$. By taking advantage of this fact, microbial community analyses have revealed the flow of stable isotopically labeled carbon from the atmosphere into microbes in the rhizosphere ${ }^{65,85)}$.

\section{Microbial community analysis in phytosphere by culture-independent methodologies}

\section{(1) Assessment of biotic and abiotic environmental factors}

The use of culture-independent methodologies to analyze microbial communities has potential when assessing the environmental impact of biotic and abiotic factors on plantassociated microbial communities in both natural and agricultural settings. Because of concerns about global warming, the impact of elevated $\mathrm{CO}_{2}$ levels upon the rhizosphere was examined as they could possibly affect microbial community structures through alterations in the carbon flow from photosynthetic activities ${ }^{49,56)}$. Similarly, the rice rhizosphere has also been subjected to microbial community analyses due to growing concerns regarding methane emission from rice fields. Lu and Conrad ${ }^{65)}$ applied a RNAbased community analysis to the identification of methanogenic Archaea in the rice rhizosphere, in combination with stable isotope-probing techniques, and have shown that a methanogenic archaea group is mainly responsible for $\mathrm{CH}_{4}$ production in rice field soil.

Methane-oxidizing bacteria (MOB) have also been recognized as an important microbial group in the reduction of methane emissions from rice agriculture. Therefore, evaluations of the community structures of this group of bacteria have been conducted by several groups ${ }^{23,40)}$, and shown that the population size and activity of MOB in the rhizosphere were mainly affected by plant growth stages. Dohrmann and Tebbe ${ }^{17)}$ have also shown that ozone stress has only small effects on the structural diversity of the bacterial communities in the rhizosphere. These findings indicate the usefulness of the culture-independent community analyses of the phytosphere to global environmental assessments.

Environmental risk assessments of genetically modified organisms (GMOs) have become one of the major areas for the application of culture-independent microbial community analyses. The impact of transgenic plants on the microbial community in the phytosphere has been examined, and was found to be negligible in comparison with natural variations such as plant growth stages and growth conditions $^{4,7,21,24,28,33,86,95,98)}$. Similarly, the impact of genetically modified rhizobia on rhizosphere microbial communities have been extensively examined ${ }^{28,92,96,107,111,112)}$. Despite a number of environmental assessments of upland transgenic crops, no transgenic rice has so far been investigated for the effects upon microbial communities in the phytosphere. However, an examination of the possible impact of transgenic rice on microbial communities may be very important environmentally, since altering the genotypes of rice plants may either increase or decrease global $\mathrm{CH}_{4}$ emissions from rice fields ${ }^{63,77,79)}$. These microbial community analyses of phytospheres could thus allow us to examine the possible impact of GMOs on the environment more comprehensively, and minimize the environmental risk in the utilization of GMOs in open fields such as the culturing of transgenic plants or releasing of genetically modified microbes as a biological control agent or a plant growth promoter.

Microbial community analyses of the phytosphere have also begun to provide new insights into the relationships between the incidence of disease and microbial diversity. Disease symptoms are not always visible on infected plants, and specific diseases can remain latent for long periods ${ }^{6,11,35,94)}$. Because the economic losses associated with latent infections are considerable for some plants, including various tree species, due to their long period of cultivation, microbial community analyses may be useful as diagnostic tests to guarantee pathogen-free conditions, at least at the time of planting ${ }^{25}$. In addition, these community analyses provide an opportunity to screen for potential new antagonistic microbes which may be useful biological control agents for plant pathogens in the phytosphere. In this regard, McSpadden-Gardener and Weller ${ }^{73)}$ have studied microbial community structures in disease suppressive soil to survey candidate antagonistic microbes responsible for this suppression. More recently, Reiter and Sessitsch ${ }^{90)}$ have reported that the high tolerance of a variety of potato against common scab may be at least partly due to its ability to host some endophytic Streptomycetes.

\section{(2) Diversity of microbial functional genes}

One of the main problems associated with analyzing microbial communities is the difficulty in interpreting any changes of the fingerprinting profiles in terms of their biological significance due to the use of rRNA gene regions. This is because most microbes in nature are unculturable and their functionality can therefore not be predicted accurately based on the analysis of their rRNA gene regions, unless the functionality can be reflected in their phylogenetic locations. In order to circumvent this problem, several studies of the diversity of microbial functional genes in the 
Table 3. PCR primers employed for the molecular analysis of functional microbial genes in the phytosphere

\begin{tabular}{|c|c|c|c|c|}
\hline $\begin{array}{c}\text { Community or } \\
\text { Organism }\end{array}$ & Target gene & Method & Primer (Forward/Reverse) ${ }^{\mathrm{a}}$ & References \\
\hline \multicolumn{5}{|l|}{ Endosphere } \\
\hline Bacteria & nifH & Sequencing & $n i f H($ for $\mathrm{A}) / n i f H(\mathrm{rev})$ and $n i f H($ forB $) / n i f H(\mathrm{rev})$ & $88)$ \\
\hline \multicolumn{5}{|l|}{ Rhizosphere } \\
\hline Bacteria & Chitinase & T-RFLP & GA1F/GA1R & 45) \\
\hline Bacteria & $m m o X$ & Sequencing & $534 f / 1393 r$ & 40) \\
\hline Bacteria & $m x a F$ & DGGE & $1003 \mathrm{~F} / 1562 \mathrm{R}$ & 23) \\
\hline Bacteria & nifH & Sequencing & nH17K-F/nH139P-R & 22) \\
\hline Bacteria & nifH & Sequencing & $n i f H($ for $\mathrm{A}) / n i f H(\mathrm{rev})$ and $n i f H($ forB $) / n i f H(\mathrm{rev})$ & 34) \\
\hline Bacteria & nifH & T-RFLP & Zehr-nifHf/Zehr-nifHr & 106) \\
\hline Bacteria & nifH & T-RFLP & nifH-F/nifH-R & 45) \\
\hline Bacteria & $\operatorname{nirK}$ & DGGE & nirK1F/nirK5R & 99) \\
\hline Bacteria & $\operatorname{nir} S$ & DGGE & nirS1F/nirS6R & 99) \\
\hline Bacteria & phlD & DGGE & DGGE292forCG/6DGGE618rev & 5) \\
\hline Bacteria & phlD & DGGE & DGGE292forCG/DGGE618rev & 5) \\
\hline Bacteria & pmoA & DGGE & A189-GC/A682 & 40) \\
\hline Bacteria & pmoA & Sequencing & $\mathrm{f} 1003 / \mathrm{r} 1561$ & 40) \\
\hline Bacteria & pmoA & T-RFLP & A189/A682 & 40) \\
\hline
\end{tabular}

a Two primer sets are shown for nested PCR.

phytosphere have been reported (Table 3). The diversity of diazotroph communities in the phytosphere has been studied extensively based on molecular analyses of the nifH genes, due to the importance of this process during crop production ${ }^{22,34,88,106)}$. Recently, Knauth et al. ${ }^{57)}$ have also shown that intraspecies genotypic variations among plants have significant influences on the diversity of the root-associated nifH genes, and suggested that the genetic factors in rice plants that stimulate $\mathrm{N}_{2}$ fixation by diazotrophs can be identified.

Microbiological denitrification also has become an important area of research due to its influence on the loss of fixed nitrogen in different environments, and on the accumulation of nitric oxide and nitrous oxide which contribute to global warming and the destruction of the stratospheric ozone layer. Similarly, Sharma et al. ${ }^{99}$ ) have examined the molecular diversity of the nirK genes, which encode a key enzyme in the denitrification process, in the rhizosphere of grain legumes.

In the phytosphere, several microbial groups are considered important for protection against plant disease. Among these, the chitinolytic bacteria are thought to be important for disease control in the phytosphere ${ }^{53,118)}$. Recently, we have examined the molecular diversity of root-associated bacterial chitinase genes, and have shown the significant influence of the rhizosphere as well as plant genotypes on the composition of the chitinolytic bacterial community ${ }^{45,48)}$. Bergsma-Vlami et al. ${ }^{5}$ have successfully assessed the genetic diversity of antagonistic Pseudomonas species based on their root colonization ability in the rhizosphere by using DGGE to target a biosynthetic gene for an antibiotic. The results of these reports reemphasize the usefulness of culture-independent methodologies for analyzing the functionality of microbial communities in the phytosphere.

\section{Conclusions}

Whereas a series of culture-independent methodologies are now available for analyzing microbial diversity and functionality, caution should be taken when performing such analyses for the phytosphere, as described in the present review. Culture-independent community analyses will not only be useful for analyzing the roles of uncultured microbes, but also provide new insights into the known beneficial or deleterious microbes in the phytosphere. The application of culture-independent methodologies will thus facilitate a better understanding of plant-microbe interactions across a broad spectrum of microbiological research.

\section{Acknowledgements}

This work was supported in part by a Grant-in-Aid for 
Scientific Research on Priority Areas ('Comparative Genomics') to K. M. and by a grant to K. M. (no. 17658034) from the Ministry of Education, Culture, Sports, Science, and Technology of Japan.

\section{References}

1) Amann, R.I., W. Ludwig, and K.H. Schleifer. 1995. Phylogenetic identification and in situ detection of individual microbial cells without cultivation. Microbial. Rev. 59:143-169.

2) Araújo, W.L., J. Marcon, W.J. Maccheroni, J.D. van Elsas, J.W.L. van Vuurde, and J.L. Azevedo. 2002. Diversity of endophytic bacterial populations and their interaction with Xylella fastidiosa in citrus plants. Appl. Environ. Microbiol. 68:49064914.

3) Asghari, H.R., P. Marschner, S.E. Smith, and F.A. Smith. 2005. Growth response of Atriplex nummularia to inoculation with arbuscular mycorrhizal fungi at different salinity levels. Plant Soil 273:245-256.

4) Baumgarte, S. and C.C. Tebbe. 2005. Field studies on the environmental fate of the Cry1 Ab Bt-toxin produced by transgenic maize (MON810) and its effect on bacterial communities in the maize rhizosphere. Mol. Ecol. 14:2539-2551.

5) Bergsma-Vlami, M., M.E. Prins, M. Staats, and J.M. Raaijmakers. 2005. Assessment of genotypic diversity of antibiotic-producing Pseudomonas species in the rhizosphere by denaturing gradient gel electrophoresis. Appl. Environ. Microbiol. 71:9931003.

6) Bouhot, G.B. 1969. Soil sickness, pp. 9-21, In Soil sickness and cultural damages in the several crops. vol. 17. I.N.R.A. publications, Paris.

7) Castaldini, M., A. Turrini, C. Sbrana, A. Benedetti, M. Marchionni, S. Mocali, A. Fabiani, S. Landi, F. Santomassimo, B. Pietrangeli, M.P. Nuti, N. Miclaus, and M. Giovannetti. 2005. Impact of Bt corn on rhizospheric and soil eubacterial communities and on beneficial mycorrhizal symbiosis in experimental microcosms. Appl. Environ. Microbiol. 71:6719-6729.

8) Chelius, M.K., and E.W. Triplett. 2001. The diversity of archaea and bacteria in association with the roots of Zea mays $\mathrm{L}$. Microb. Ecol. 41:252-263.

9) Cocking, E.C. 2003. Endophytic colonisation of plant roots by nitrogen-fixing bacteria. Plant Soil 252:169-175.

10) Conn, V.M., and C.M.M. Franco. 2004. Analysis of the endophytic actinobacterial population in the roots of wheat (Triticum aestivum L.) by terminal restriction fragment length polymorphism and sequencing of 16S rRNA clones. Appl. Environ. Microbiol. 70:1787-1794.

11) Cook, R.J., and W.A. Haglund. 1982. Pythium root rot: a barrier to yield of pacific northwest wheat. Washington State Unversity College of Agriculture Research Bulletin No. XB0193:1-18.

12) Costa, R., M. Götz, N. Mrotzek, J. Lottmann, G. Berg, and K. Smalla. 2006. Effects of site and plant species on rhizosphere community structure as revealed by molecular analysis of microbial guilds. FEMS Microbiol. Ecol. 56:236-249.

13) Costa, R., J.F. Salles, G. Berg, and K. Smalla. 2006. Cultivationindependent analysis of Pseudomonas species in soil and in the rhizosphere of field-grown Verticillium dahliae host plants. Environ. Microbiol. 8:2136-2149.
14) De Ridder-Duine, A.S., G.A. Kowalchuk, P.J.A. Klein Gunnewiek, W. Smant, J.A. van Veen, and W. de Boer. 2005. Rhizosphere bacterial community composition in natural stands of Carex arenaria (sand sedge) is determined by bulk soil community composition. Soil Biol. Biochem. 37:349-357.

15) Dent, K.C., J.R. Stephen, and W.E. Finch-Savage. 2004. Molecular profiling of microbial communities associated with seeds of Beta vulgaris subsp. vulgaris (sugar beet). J. Microbiol. Methods 56:17-26.

16) Derakshani, M., T. Lukow, and W. Liesack. 2001. Novel bacterial lineages at the (sub) dvision level as detected by signature nucleotide-targeted recovery of $16 \mathrm{~S}$ rRNA genes from bulk soil and rice roots of flooded rice microcosms. Appl. Environ. Microbiol. 67:623-631.

17) Dohrmann, A.B., and C.C. Tebbe. 2005. Effect of elevated tropospheric ozone on the structure of bacterial communities inhabiting the rhizosphere of herbaceous plants native to Germany. Appl. Environ. Microbiol. 71:7750-7758.

18) Duineveld, B.M., G.A. Kowalchuk, A. Keijzer, J.D. van Elsas, and J.A. van Veen. 2001. Analysis of bacterial communities in the rhizosphere of chrysanthemum via denaturing gradient gel electrophoresis of PCR-amplified 16S rRNA as well as DNA fragments coding for 16S rRNA. Appl. Environ. Microbiol. 67:172-178.

19) Duineveld, B.M., A.S. Rosado, J.D. van Elsas, and J.A. van Veen. 1998. Analysis of the dynamics of bacterial communities in the rhizosphere of the chrysanthemum via denaturing gradient gel electrophoresis and substrate utilization patterns. Appl. Environ. Microbiol. 64:4950-4957.

20) Dunbar, J., L.O. Ticknor, and C.R. Kuske. 2000. Assessment of microbial diversity in four southwestern United States soils by 16S rRNA gene terminal restriction fragment analysis. Appl. Environ. Microbiol. 66:2943-2950.

21) Dunfield, K.E., and J.J. Germida. 2003. Seasonal changes in the rhizosphere microbial communities associated with field-grown genetically modified canola (Brassica napus). Appl. Environ. Microbiol. 69:7310-7318.

22) Elbeltagy, A., and Y. Ando. 2005. Phylogenetic analysis of nifH gene sequences from nitrogen-fixing endophytic bacteria associated with the roots of three rice varieties. J. Food, Agri. Environ. 3:237-242.

23) Eller, G., M. Krüger, and P. Frenzel. 2005. Comparing field and microcosm experiments: a case study on methano- and methylotrophic bacteria in paddy soil. FEMS Microbiol. Ecol. 51:279291.

24) Fang, M., R.J. Kremer, P.P. Motavalli, and G. Davis. 2005. Bacterial diversity in rhizospheres of nontransgenic and transgenic corn. Appl. Environ. Microbiol. 71:4132-4136.

25) Filion, M., R.C. Hamelin, L. Bernier, and M. St-Arnaud. 2004. Molecular profiling of rhizosphere microbial communities associated with healthy and diseased Black Spruce (Picea mariana) seedlings grown in a nursery. Appl. Environ. Microbiol. 70:3541-3551.

26) Furuya, H., T. Matsumoto, S. Fuji, and H. Naito. 2003. Inconspicuous restraint of rice seedling growth by root infecting fungi in soil of a rice paddy field. J. Gen. Plant Pathol. 69:115-119.

27) Furuya, H., K. Tubaki, T. Matsumoto, S. Fuji, and H. Naito. 2005. Deleterious effects of fungi isolated from paddy soils on seminal root of rice. J. Gen. Plant Pathol. 71:333-339.

28) Götz, M., H. Nirenberg, S. Krause, H. Wolters, S. Draeger, A. 
Buchner, J. Lottmann, G. Berg, and K. Smalla. 2006. Fungal endophytes in potato roots studied by traditional isolation and cultivation-independent DNA-based methods. FEMS Microbiol. Ecol. 58:404-413.

29) Garbeva, P., L.S. Overbeek, J.W. Vuurde, and J.D. Elsas. 2001. Analysis of endophytic bacterial communities of potato by plating and denaturing gradient gel electrophoresis (DGGE) of $16 \mathrm{~S}$ rDNA based PCR fragments. Microb. Ecol. 41:369-383.

30) Geroge, E., H. Marschner, and I. Jakobsen. 1995. Role of arbuscular mycorrhizal fungi in up take of phosphorus and nitrogen from soil. Crit. Rev. Biotechnol. 15:257-270.

31) Gomes, N.C.M., O. Fagbola, R. Costa, N.G. Rumjanek, A. Buchner, L. Mendona-Hagler, and K. Smalla. 2003. Dynamics of fungal communities in bulk and maize rhizosphere soil in the tropics. Appl. Environ. Microbiol. 69:3758-3766.

32) Green, S.J., E. Inbar, F.C. Michel Jr., H. Hadar, and D. Minz. 2006. Succession of bacterial communities during early plant development: transition from seed to root and effect of compost amendment. Appl. Environ. Microbiol. 72:3975-3983.

33) Gyamfi, S., U. Pfeifer, M. Stierschneider, and A. Sessitsch. 2002. Effects of transgenic glufosinate-tolerant oilseed rape (Brassica napus) and the associated herbicide application on eubacterial and Pseudomonas communities in the rhizosphere. FEMS Microbiol. Ecol. 41:181-190.

34) Hamelin, J., N. Fromin, S. Tarnawski, S. Teyssier-Cuvelle, and M. Aragno. 2002. nifH gene diversity in the bacterial community associated with the rhizosphere of Molinia coerulea, an oligonitrophilic perennial grass. Environ. Microbiol. 4:477-481.

35) Hamelin, R.C., P. Bérubé, M. Gignac, and M. Bourassa. 1996. Identification of root rot fungi in nursery seedlings by nested multiplex PCR. Appl. Environ. Microbiol. 62:4026-4031.

36) Heuer, H., R.M. Kroppenstedt, J. Lottmann, G. Berg, and K. Smalla. 2002. Effects of T4 lysozyme release from transgenic potato roots on bacterial rhizosphere communities are negligible relative to natural factors. Appl. Environ. Microbiol. 68:13251335.

37) Heuer, H., M. Krsek, P. Baker, K. Smalla, and E.M. Wellington. 1997. Analysis of actinomycete communities by specific amplification of genes encoding 16S rRNA and gel-electrophoretic separation in denaturing gradients. Appl. Environ. Microbiol. 63:3233-3241.

38) Heuer, H., and K. Smalla. 1999. Bacterial phyllosphere communities of Solanum tuberosum L. and T4-lysozyme-producing transgenic variants. FEMS Microbiol. Ecol. 28:357-371.

39) Hirano, S., and C. Upper. 1990. Population biology and epidemiology of Pseudomonas syringae. Annu. Rev. Phytopathol. 28:155-177.

40) Horz, H.P., M.T. Yimga, and W. Liesack. 2001. Detection of methanotroph diversity on roots of submerged rice plants by molecular retrieval of pmoA, mmoX, mxaF, and 16S rRNA and ribosomal DNA, including $p m o A$-based terminal restriction fragment length polymorphism profiling. Appl. Environ. Microbiol. 67:4177-4185.

41) Idris, R., R. Trifonova, M. Puschenreiter, W.W. Wenzel, and A. Sessitsch. 2004. Bacterial communities associated with flowering plants of the Ni hyperaccumulator Thlaspi goesingense. Appl. Environ. Microbiol. 70:2667-2677.

42) Ikeda, S., S. Fuji, T. Sato, H. Furuya, H. Naito, N. Ytow, H. Ezura, K. Minamisawa, and T. Fujimura. 2007. Microbial diversity in milled rice as revealed by ribosomal intergenic spacer analysis. Microbes Environ. 22: In press.

43) Ikeda, S., S. Fuji, T. Sato, N. Ytow, H. Ezura, K. Minamisawa, and T. Fujimura. 2006. Community analysis of seed-associated microbes in forage crops using culture-independent methods. Microbes Environ. 21:112-121.

44) Ikeda, S., T. Fujimura, and N. Ytow. 2005. Potential application of ribosomal intergenic spacer analysis to the microbial community analysis of agronomic products. J. Agric. Food Chem. 53:5604-5611.

45) Ikeda, S., T. Omura, N. Ytow, H. Komaki, K. Minamisawa, H. Ezura, and T. Fujimura. 2006. Microbial community analysis in the rhizosphere of a transgenic tomato that overexpresses 3Hydroxy-3-methylglutaryl coenzyme A reductase. Microbes Environ. 21:261-271.

46) Ikeda, S., H. Shinoyama, Y. Yamanaka, N. Ytow, H. Ezura, and T. Fujimura. 2005. Application of ribosomal intergenic spacer analysis to the characterization of microbial communities in rhizospheric soils of the $B t$ transgenic chrysanthemum. Microbes Environ. 20:258-263.

47) Ikeda, S., N. Ytow, H. Ezura, K. Minamisawa, and T. Fujimura. 2006. Soil microbial community analysis in the environmental risk assessment of transgenic plants. Plant Biotechnol. 23:137151.

48) Ikeda, S., N. Ytow, H. Ezura, K. Minamisawa, K. Miyashita, and T. Fujimura. 2007. Analysis of the molecular diversity of bacterial chitinase genes in the maize rhizosphere using cultureindependent methods. Microbes Environ. 22:71-77.

49) Janus, L.R., N.L. Angeloni, J. McCormack, S.T. Rier, N.C. Tuchman, and J.J. Kelly. 2005. Elevated atmospheric $\mathrm{CO}_{2}$ alters soil microbial communities associated with trembling aspen (Populus tremuloides) roots. Microbial. Ecol. 50:102-109.

50) Kadivar, H. and A.E. Stapleton. 2003. Ultraviolet radiation alters maize phyllosphere bacterial diversity. Microb. Ecol. 45:353-361.

51) Kent, A.D. and E.W. Triplett. 2002. Microbial communities and their interactions in soil and rhizosphere ecosystems. Annu. Rev. Microbiol. 56:211-236.

52) Kerkhof, L., M. Santoro, and J. Garland. 2000. Response of soybean rhizosphere communities to human hygiene water addition as determined by community level physiological profiling (CLPP) and terminal restriction fragment length polymorphism (TRFLP) analysis. FEMS Microbiol. Lett. 184:95-101.

53) Kerry, B.R. 2000. Rhizosphere interactions and the exploitation of microbial agents for the biological control of plant-parasitic nematodes. Annu. Rev. Phytopathol. 38:423-441.

54) Kimura, N. 2006. Metagenomics: access to unculturable microbes in the environment. Microbes Environ. 21:201-215.

55) Kirk, J.L., L.A. Beaudette, M. Hart, P. Moutoglis, J.N. Klironomos, H. Lee, and J.T. Trevors. 2004. Methods of studying soil microbial diversity. J. Microbiol. Methods 58:169-188.

56) Klamer, M., M.S. Roberts, L.H. Levine, B.G. Drake, and J.L. Garland. 2002. Influence of elevated $\mathrm{CO}_{2}$ on the fungal community in a coastal scrub oak forest soil investigated with terminalrestriction fragment length polymorphism analysis. Appl. Environ. Microbiol. 68:4370-4376.

57) Knauth, S., T. Hurek, D. Brar, and B. Reinhold-Hurek. 2005. Influence of different Oryza cultivars on expression of nifH gene pools in roots of rice. Environ. Microbiol. 7:1725-1733.

58) Kowalchuk, G.A. 1999. Fungal community analysis using denaturing gradient gel electrophoresis (DGGE), pp. 1-16. In A.D.L. 
Akkermans, J.D. van Elsas, and F.J. de Bruijn (eds.), Molecular Microbial Ecology Mannual, vol. 3.4.6. Kluwer Academic Publisher, Dordrecht.

59) Kowalchuk, G.A., D.S. Buma, W. de Boer, P.G.L. Klinkhamer, and J.A. van Veen. 2002. Effects of above-ground plant species composition and diversity on the diversity of soil-borne microorganisms. Antonie van Leeuwenhoek 81:509-520.

60) Kowalchuk, G.A., F.A. De Souza, and J.A. van Veen. 2002. Community analysis of arbuscular mycorrhizal fungi associated with Ammophila arenaria in Dutch coastal sand dunes. Mol. Ecol. 11:571-581.

61) Kowalchuk, G.A., S. Gerards, and J.W. Woldendorp. 1997. Detection and characterization of fungal infections of Ammophila arenaria (marram grass) roots by denaturing gradient gel electrophoresis of specifically amplified $18 \mathrm{~S}$ rDNA. Appl. Environ. Microbiol. 63:3858-3865.

62) Kuske, C.R., S.M. Barns, and J.D. Busch. 1997. Diverse uncultivated bacterial groups from soils of the arid southwestern United States that are present in many geographic regions. Appl. Environ. Microbiol. 63:3614-3621.

63) Lelieveld, J., P.J. Crutzen, and F.J. Dentener. 1998. Changing concentration, lifetime and climate forcing of atmospheric methane. Tellus Series B-Chem. Phys. Meteorol. 50:128-150.

64) Lottmann, J., H. Heuer, J. de Vries, A. Mahn, K. Düring, W. Wackernagel, K. Smalla, and G. Berg. 2000. Establishment of introduced antagonistic bacteria in the rhizosphere of transgenic potatoes and their effect on the bacterial community. FEMS Microbiol. Ecol. 33:41-49.

65) Lu, Y., and R. Conrad. 2005. In situ stable isotope probing of methanogenic Archaea in the rice rhizosphere. Science 309:1088-1090.

66) Maarit Niemi, R., I. Heiskanen, K. Wallenius, and K. Lindstrom. 2001. Extraction and purification of DNA in rhizosphere soil samples for PCR-DGGE analysis of bacterial consortia. J. Microbiol. Methods 45:155-165.

67) MacNaughton, S.J., J.R. Stephen, A.D. Venosa, G.A. Davis, Y.J. Chang, and D.C. White. 1999. Microbial population changes during bioremediation of an experimental oil spill. Appl. Environ. Microbiol. 65:3566-3574.

68) Marcial Gomes, N.C., O. Fagbola, R. Costa, N.G. Rumjanek, A. Buchner, L. Mendona-Hagler, and K. Smalla. 2003. Dynamics of fungal communities in bulk and maize rhizosphere soil in the tropics. Appl. Environ. Microbiol. 69:3758-3766.

69) Marschner, P., and K. Baumann. 2003. Changes in bacterial community structure induced by mycorrhizal colonisation in split-root maize. Plant Soil 251:279-289.

70) Marschner, P., D. Crowley, and C.H. Yang. 2004. Development of specific rhizosphere bacterial communities in relation to plant species, nutrition and soil type. Plant Soil 261:199-208.

71) Marschner, P., D.E. Crowley, and R. Lieberei. 2001. Arbuscular mycorrhizal infection changes the bacterial $16 \mathrm{~S}$ rDNA community composition in the rhizosphere of maize. Mycorrhiza 11:297-302.

72) Marschner, P., G. Neumann, A. Kania, L. Weiskopf, and R. Lieberei. 2002. Spatial and temporal dynamics of the microbial community structure in the rhizosphere of cluster roots of white lupin (Lupinus albus L.). Plant Soil 246:167-174.

73) McSpadden Gardener, B.B., and D.M. Weller. 2001. Changes in populations of rhizosphere bacteria associated with take-all disease of wheat. Appl. Environ. Microbiol. 67:4414-4425.
74) McVeigh, H.P., J. Munro, and T.M. Embley. 1996. Molecular evidence for the presence of novel actinomycete lineages in a temperate forest soil. J. Ind. Microbiol. Biotechnol. 17:197-204.

75) Merbach, W., E. Mirus, G. Knof, R. Remus, S. Ruppel, R. Russow, A. Gransee, and J. Schulze. 1999. Release of carbon and nitrogen compounds by plant roots and their possible ecological importance. J. Plant Nutr. Soil Sci. 162:373-383.

76) Milling, A., K. Smalla, F.X. Maidl, M. Schloter, and J.C. Munch. 2005. Effects of transgenic potatoes with an altered starch composition on the diversity of soil and rhizosphere bacteria and fungi. Plant Soil 266:23-39.

77) Minamikawa, K., N. Sakai, and K. Yagi. 2006. Methane emission from paddy fields and its mitigation options on a field scale. Microbes Environ. 21:135-147.

78) Minamisawa, K., K. Nishioka, T. Miyaki, B. Ye, T. Miyamoto, M. You, A. Saito, M. Saito, W.L. Barraquio, N. Teaumroong, T. Sein, and T. Sato. 2004. Anaerobic nitrogen-fixing consortia consisting of clostridia isolated from gramineous plants. Appl. Environ. Microbiol. 70:3096-3102.

79) Neue, H.U. 1997. Fluxes of methane from rice fields and potential for mitigation. Soil Use Manage. 13:258-267.

80) Nishijima, T., K. Toyota, and M. Mochizuki. 2005. Predominant culturable Bacillus species in japanese arable soils and their potential as biocontrol agents. Microbes Environ. 20:61-68.

81) Normander, B. and J.I. Prosser. 2000. Bacterial origin and community composition in the barley phytosphere as a function of habitat and presowing conditions. Appl. Environ. Microbiol. 66:4372-4377.

82) Nunan, N., T.J. Daniell, B.K. Singh, A. Papert, J.W. McNicol, and J.I. Prosser. 2005. Links between plant and rhizoplane bacterial communities in grassland soils, characterized using molecular techniques. Appl. Environ. Microbiol. 71:6784-6792.

83) Pace, N.R. 1997. A molecular view of microbial diversity and the biosphere. Science 276:734-740.

84) Pinton, R., Z. Varanini, and P. Nannipieri. 2001. The rhizosphere: biochemistry and organic substances at the soil-plant interface. Marcel Dekker, New York.

85) Rangel-Castro, J.I., K. Killham, N. Ostle, G.W. Nicol, I.C., anderson, C.M. Scrimgeour, P. Ineson, A. Meharg, and J.I. Prosser. 2005. Stable isotope probing analysis of the influence of liming on root exudate utilization by soil microorganisms. Environ. Microbiol. 7:828-838.

86) Rasche, F., V. Hödl, C. Poll, E. Kandeler, M.H. Gerzabek, J.D. van Elsas, and A. Sessitsch. 2006. Rhizosphere bacteria affected by transgenic potatoes with antibacterial activities compared with the effects of soil, wild-type potatoes, vegetation stage and pathogen exposure. FEMS Microbiol. Ecol. 56:219-235.

87) Rasche, F., R. Trondl, C. Naglreiter, T.G. Reichenauer, and A. Sessitsch. 2006. Chilling and cultivar type affect the diversity of bacterial endophytes colonizing sweet pepper (Capsicum annum L.). Can. J. Microbiol. 52:1036-1045.

88) Reiter, B., H. Burgmann, K. Burg, and A. Sessitsch. 2003. Endophytic nifH gene diversity in African sweet potato. Can. J. Microbiol. 49:549-555.

89) Reiter, B., U. Pfeifer, H. Schwab, and A. Sessitsch. 2002. Response of endophytic bacterial communities in potato plants to infection with Erwinia carotovora subsp. atroseptica. Appl. Environ. Microbiol. 68:2261-2268.

90) Reiter, B., and A. Sessitsch. 2006. Bacterial endophytes of the wildflower Crocus albiflorus analyzed by characterization of 
isolates and by a cultivation-independent approach. Can. J. Microbiol. 52:140-149.

91) Reiter, B., N. Wermbter, S. Gyamfi, H. Schwab, and A. Sessitsch. 2003. Endophytic Pseudomonas spp. populations of pathogen-infected potato plants analysed by $16 \mathrm{~S}$ rDNAand 16S rRNA-based denaturating gradient gel electrophoresis. Plant Soil 257:397-405.

92) Robleto, E.A., J. Borneman, and E.W. Triplett. 1998. Effects of bacterial antibiotic production on rhizosphere microbial communities from a culture-independent perspective. Appl. Environ. Microbiol. 64:5020-5022.

93) Salles, J.F., F.A. De Souza, and J.D. van Elsas. 2002. Molecular method to assess the diversity of Burkholderia species in environmental samples. Appl. Environ. Microbiol. 68:1595-1603.

94) Salt, G.A. 1979. The increasing interest in 'minor pathogens', pp. 289-312. In B. Shippers, and W. Gams (eds.), Soil-borne plant pathogens. Academic Press, London.

95) Schmalenberger, A., and C.C. Tebbe. 2003. Genetic profiling of noncultivated bacteria from the rhizospheres of sugar beet (Beta vulgaris) reveal field and annual variability but no effect of a transgenic herbicide resistance. Can. J. Microbiol. 49:1-8.

96) Schwieger, F., and C.C. Tebbe. 2000. Effect of field inoculation with Sinorhizobium meliloti L33 on the composition of bacterial communities in rhizospheres of a target plant (Medicago sativa) and a nontarget plant (Chenopodium album): linking of $16 \mathrm{~S}$ rRNA gene-based single-strand conformation polymorphism community profiles to the diversity of cultivated bacteria. Appl. Environ. Microbiol. 66:3556-3565.

97) Seghers, D., L. Wittebolle, E.M. Top, W. Verstraete, and S.D. Siciliano. 2004. Impact of agricultural practices on the Zea mays L. endophytic community. Appl. Environ. Microbiol. 70:14751482.

98) Sessitsch, A., B. Reiter, U. Pfeifer, and E. Wilhelm. 2002. Cultivation-independent population analysis of bacterial endophytes in three potato varieties based on eubacterial and Actinomycetes specific PCR of 16S rRNA genes. FEMS Microbiol. Ecol. 39:23-32.

99) Sharma, S., M.K. Aneja, J. Mayer, J.C. Munch, and M. Schloter. 2005. Diversity of transcripts of nitrite reductase genes (nirK and nirS) in rhizospheres of grain legumes. Appl. Environ. Microbiol. 71:2001-2007.

100) Sharma, S., M.K. Aneja, J. Mayer, M. Schloter, and J.C. Munch. 2004. RNA fingerprinting of microbial community in the rhizosphere soil of grain legumes. FEMS Microbiol. Lett. 240:181186.

101) Shivanna, M.B., M.S. Meera, M. Kubota, and M. Hyakumachi. 2005. Promotion of growth and yield in cucumber by zoysiagrass rhizosphere fungi. Microbes Environ. 20:34-40.

102) Sliwinski, M.K., and R.M. Goodman. 2004. Comparison of crenarchaeal consortia inhabiting the rhizosphere of diverse terrestrial plants with those in bulk soil in native environments. Appl. Environ. Microbiol. 70:1821-1826.

103) Smalla, K., G. Wieland, A. Buchner, A. Zock, J. Parzy, S. Kaiser, N. Roskot, H. Heuer, and G. Berg 2001. Bulk and rhizo- sphere soil bacterial communities studied by denaturing gradient gel electrophoresis: plant-dependent enrichment and seasonal shifts revealed. Appl. Environ. Microbiol. 67:4742-4751.

104) Smith, K.P. and R.M. Goodman. 1999. Host variation for interactions with beneficial plant-associated microbes. Annu. Rev. Phytopathol. 37:473-491.

105) Stafford, W.H., G.C. Baker, S.A. Brown, S.G. Burton, and D.A. Cowan. 2005. Bacterial diversity in the rhizosphere of Proteaceae species. Environ. Microbiol. 7:1755-1768.

106) Tan, Z., T. Hurek, and B. Reinhold-Hurek. 2003. Effect of Nfertilization, plant genotype and environmental conditions on nifH gene pools in roots of rice. Environ. Microbiol. 5:10091015.

107) Timms-Wilson, T.M., K. Kilshaw, and M.J. Bailey. 2005. Risk assessment for engineered bacteria used in biocontrol of fungal disease in agricultural crops. Plant Soil 266:57-67.

108) Timonen, S., R.D. Finley, S. Olsson, and B. Soderstrom. 1996. Dynamics of phosphorus translocation in intact ectomyorrhizal systems: non-destructive monitoring using a B-scanner. FEMS Microbiol. Ecol. 19:171-180.

109) Torsvik, V., J. Goksøyr, and F.L. Daae. 1990. High diversity in DNA of soil bacteria. Appl. Environ. Microbiol. 56:782-787.

110) Trulove, S.N., M.J. Hedley, G.J.D. Kirk, N.S. Bolan, and P. Loganathan. 2003. Progress in selected areas of rhizosphere on P acquisition. Aust. J. Soil Res. 41:471-499.

111) van Dillewijn, P., P.J. Villadas, and N. Toro. 2002. Effect of a Sinorhizobium meliloti strain with a mdified putA gene on the rhizosphere microbial community of alfalfa. Appl. Environ. Microbiol. 68:4201-4208.

112) Viebahn, M., R. Doornbos, K. Wernars, L.C. van Loon, E. Smit, and P.A.H.M. Bakker. 2005. Ascomycete communities in the rhizosphere of field-grown wheat are not affected by introductions of genetically modified Pseudomonas putida WCS358r. Environ. Microbiol. 7:1775-1785.

113) Viebahn, M., C. Veenman, K. Wernars, L.C. van Loon, E. Smit, and P.A.H.M. Bakker. 2005. Assessment of differences in ascomycete communities in the rhizosphere of field-grown wheat and potato. FEMS Microbiol. Ecol. 53:245-253.

114) Wagner, R. 1994. The regulation of ribosomal RNA synthesis and bacterial cell growth. Arch. Microbiol. 161:100-109.

115) Wieland, G., R. Neumann, and H. Backhaus. 2001. Variation of microbial communities in soil, rhizosphere, and rhizoplane in response to crop species, soil type, and crop development. Appl. Environ. Microbiol. 67:5849-5854.

116) Yang, C.H. and D.E. Crowley. 2000. Rhizosphere microbial community structure in relation to root location and plant iron nutritional status. Appl. Environ. Microbiol. 66:345-351.

117) Yang, C.H., D.E. Crowley, J. Borneman, and N.T. Keen. 2001. Microbial phyllosphere populations are more complex than previously realized. Proc. Natl. Acad. Sci. USA 98:3889-3894.

118) Zhang, Z. and G.Y. Yuen. 2000. The role of chitinase production by Stenotrophomonas maltophilia strain C3 in biological control of Bipolaris sorokiniana. Phytopathology 90:384-389. 